\title{
Pengembangan Media Animasi Dengan Aplikasi Makromedia Flash Untuk Meningkatkan Sikap Ilmiah Siswa
}

\author{
Baiq azmi sukroyanti ${ }^{1)}$, baiq rina amalia safitri ${ }^{2)}$ \\ 1) , 2) Program Studi Pendidikan Fisika FPMIPA IKIP Mataram
}

Email : bqazmi@ikipmataram.ac.id

\begin{abstract}
ABSTRAK : Pengembangan media pembelajaran sangatlah penting guna mendukung proses belajar mengajar di kelas, selain mempengaruhi hasil belajar dapat juga mempengaruhi sikap ilmiah, Sikap ilmiah difokuskan pada terbuka, kritis, teliti, rasa ingin tahu, tekun, jujur, tanggung jawab. Penelitian ini bertujuan untuk (1) Mengembangkan Media Animasi dengan Aplikasi Makromedia Flash pada Materi Getaran; (2) Mengetahui peningkatkan sikap ilmiah dengan media animasi yang dikembangkan. Jenis penelitian ini adalah penelitian pengembangan research and development (R\&D). Produk media media animasi pembelajaran fisika pokok bahasan getaran yang telah dikembangkan oleh peneliti dengan menggunakan perangkat lunak komputer macromediaflash termasuk dalam kategori sangat baik. Hasil validasi ahli media oleh validator 1 skor 3.4 dengan kategori sangat baik, sedangkan hasil validasi ahli materi oleh validator 2 sebesar 3.3 dengan kategori sangat baik dan hasil perolehan skor rata-rata dari keseluruhan siswa/responden terhadap media animasi pembelajaran fisika yang dikembangkan termasuk dalam kategori sangat setuju. Dari 20 siswa/responden 5 siswa merespon dengan kategori setuju dan 15 siswa merespon dengan kategori sangat setuju. Dengan demikian media animasi pembelajaran fisika pokok bahasan getaran yang dikembangkan layak dijadikan sebagai media animasi pembelajaran. Pengembangan media animasi dengan Aplikasi Makromedia Flash dapat meningkatkan sikap ilmiah siswa dengan kategori sangat baik pada 7 aspek yakni : terbuka, kritis, teliti, rasa ingin tahu, tekun, jujur, tanggung jawab.
\end{abstract}

Kata kunci: Media animasi, Macromedia flash, sikap ilmiah

\section{PENDAHULUAN}

Fisika sebagai salah satu rumpun Ilmu Pengetahuan Alam (IPA) atau sains, selama ini merupakam mata pelajaran yang sering ditakuti siswa karena dianggap sulit untuk dipahami dan dipelajari. Kesulitan ini timbul karena siswa kurang memahami materi. Selain itu, ilmu fisika juga terkait dengan konsep-konsep yang seringkali sulit untuk dianalogikan dengan kehidupan sehari-hari, yang nantinya berimbas pada sikap ilmiah siswa terhadap materi fisika, Untuk membentuk sikap ilmiah yang baik diperlukan kreativitas guru dalam menyajikan materi tersebut. Guru harus menemukan dan memilih model pembelajaran yang sesuai dengan materi yang diajarkan.

Faktor-faktor yang mempengaruhi kurang berhasilnya pembelajaran adalah guru dalam memilih model pembelajaran tidak sesuai dengan karakteristik materi pembelajaran, sehingga mempengaruhi guru dalam menentukan media yang digunakan, guru kurang memberikan kesempatan pada siswa untuk berperan aktif dalam memahami konsep-konsep yang harus dikuasai siswa, pembelajaran masih berlangsung transfer pengetahuan, hanya dalam bentuk hafalan dan masih jauh dari konsep pemberdayaan berpikir. Hal ini berakiat keaktifan dan keterampilan siswa cendrung diabaikan [1].

Berdasarkan hasil wawancara dengan guru mata pelajaran fisika SMKN 1 Lingsar yang dilaksanakan pada tanggal 31 Januari 2019 didapatkan informasi bahwa kurikulum yang dijadikan sebagai pedoman dalam melaksanakan proses pembelajaran adalah kurikulum 2013. Permasalahan yang umum dihadapi guru dalam melaksanakan pembelajaran siswa kurang memahami hakikat fisika yang diajarkan namun hanya terdapat sebagian sebagian siswa yang memahami hakikat materi yang diajarakan. Selain itu guru juga menyatakan bahwa selama proses pembelajaran belum pernah melibatkan penerapan media seperti media animasi dalam proses pembelajaran sebagai sarana pendukung meskipun terdapat banyak LCD, padahal dengan menerapkan media dapat lebih mempermudah dalam melaksanakan proses pembelajaran juga lebih mengefektifkan dan mengefiensi penggunaan waktu. Demikian halnya pernyataan dari beberapa siswa, selama proses pembelajaran belum pernah belajar menggunakan media seperti animasi dalam proses pembelajaran. Kemudian media sebagai salah satu sarana atau media pembelajaran kurang dimanfaatkan. Siswa juga menyatakan kesulitan dalam memahami konsep-konsep fisika dan belum menunjukkan sikap ilmiah selama proses pembelajaran berlangsung, yang diajarkan karena terlalu banyak rumus-rumus rumit yang harus dipelajari, hal ini dapat mempengaruhi sikap ilmiah siswa terhadap materi yang diajarkan. 


\section{METODE PENELITIAN}

\section{Jenis Penelitian}

Jenis penelitian ini menggunakan metode penelitian dan pengembangan (Research and Development) merupakan metode penelitian yang digunakan untuk menghasilkan produk tertentu, dan meguji keefektifan produk tersebut. Educational Research and Development juga biasa disebut Research Based Development. "Educational Research and Development is a procces used to develop and validate educational products" (Borg and Gall; 1989).

Model dalam penelitian pengembangan ini merupakan model yang menggariskan pada langkah-langkah pengembangan. Langkah-langkah yang harus diikuti untuk menghasilkan produk meliputi; potensi dan masalah, pengumpulan data, desain produk, validasi desain, revisi desain, uji coba produk, revisi produk, uji coba pemakaian, revisi produk, dan produksi masal. Pada penelitian pengembagan ini mengacu pada prosedur penelitian pengembangan menurut Sugiyono yang disesuaikan dengan kebutuhan peneliti [2].

\section{Teknik Pengumpulan Data}

Pada penelitian ini teknik yang digunakan adalah sebagai berikut: (1) Data kelayakan media diperoleh dengan berkonsultasi pada pakar/ahli (expert) media; (2) Data respon siswa diperoleh dari angket respon atau tanggapan siswa terhadap media animasi yang dikembangkan; (3) Data ketercapaian Sikap Ilmiah siswa diperoleh dengan teknik pemberian angket.

\section{Teknik Analisa Data}

Data yang dianalisis dalam penelitian ini adalah data dari lembar validator media, angket respon siswa, dan hasil pemahaman konsep siswa.

Analisis data kelayakan hasil validasi oleh validator ahli akan dianalisis secara deskriptif kualitatif, yaitu dengan memberikan gambaran dan paparan kualitas dari media pembelajaran. Perolehan data dari penilaian ahli (expert) dianalisis dan sikap ilmiah siswa dianalisis menggunakan langkah-langkah sebagai berikut:

Menghitung skor rata-rata penilaian menggunakan rumus:

$$
\bar{X}=\frac{\Sigma X}{N}
$$

Keterangan:

$\bar{X} \quad$ : Skor rata-rata

$\Sigma X:$ Jumlah skor

$N$ : Jumlah butir pertanyaan

Mengubah skor rata-rata yang diperoleh ke dalam bentuk kualitatif berdasarkan Tabel berikut:
Tabel 1. Kriteria Penilaian Produk

\begin{tabular}{ll}
\hline Skor rata-rata $(\bar{X})$ & Kriteria \\
\hline $3,25<\bar{X} \leq 4,00$ & Sangat baik \\
$2,50<\bar{X} \leq 3,25$ & Baik \\
$1,75<\bar{X} \leq 2,50$ & Kurang Baik \\
$1,00<\bar{X} \leq 1,75$ & Sangat Kurang Baik \\
\hline
\end{tabular}

Tabel 2. Kriteria Penilaian Respon Siswa

\begin{tabular}{cl}
\hline Skor rata-rata $(\bar{X})$ & Kriteria \\
\hline $0,00<\bar{X} \leq 20$ & Sangat baik \\
$20<\bar{X} \leq 40$ & Baik \\
$40<\bar{X} \leq 60$ & Cukup \\
$60<\bar{X} \leq 60$ & Kurang \\
$80<\bar{X} \leq 100$ & Sangat kurang \\
\hline
\end{tabular}

\section{HASIL DAN PEMBAHASAN}

Berdasarkan analisis data, dari penelitian ini dapat dideskripsikan sikap ilmiah siswa kelas $\mathrm{X}$ perikanan SMKN 1 Lingsar pada pembelajaran Fisika dengan media animasi dengan aplikasi makromediflash pada materi getaran serta korelasi (hubungan) antara sikap ilmiah dan hasil belajar Fisika siswa.

Sikap ilmiah siswa pada pembelajaran Fisika Dari pengolahan data hasil penelitian didapatkan rata-rata skor sikap ilmiah siswa kelas X perikanan SMKN 1 Lingsar pada pembelajaran Fisika dengan media animasi dengan aplikasi makromediflash pada materi getaran sebesar 4,52. Berdasarkan rentang kategori sikap ilmiah yang telah ditetapkan sebelumnya, rata-rata skor tersebut termasuk dalam kategori sikap ilmiah baik, karena terletak pada kisaran 4,2 - 5,0. Skor tertinggi dimiliki oleh siswa dengan nomor urut $1,13,15,16$, yaitu 4,8 , dari skor maksimum. 5,0. Sementara itu skor terendah dimiliki oleh siswa dengan nomor urut 14 yakni 3,9 dari skor minimum 10. Untuk kategori sikap ilmiah individu siswa, dari 20 siswa diperoleh bahwa \% tergolong baik; dan $95 \%$ tergolong sangat baik

Setelah dilakukan analisis aspek sikap ilmiah siswa pada pembelajaran $X$ perikanan SMKN 1 Lingsar pada pembelajaran Fisika dengan media animasi dengan aplikasi makromediflash pada materi getaran, diperoleh bahwa aspek tertinggi adalah aspek tanggung jawab dengan ratarata 4,8 dan tergolong ke dalam kategori sangat baik. Sedangkan rata-rata aspek sikap ilmiah yang terendah adalah aspek berpikir kritis yang rata-ratanya 4,15 serta tergolong dalam kategori sangat baik (Gambar 1). 


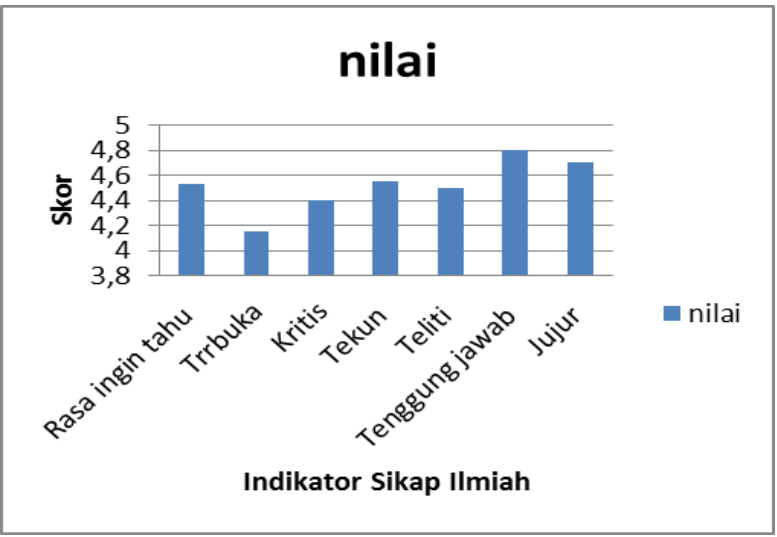

Gambar 1. Rata-rata aspek sikap ilmiah $\mathrm{X}$ perikanan SMKN 1 Lingsar pada pembelajaran Fisika dengan media animasi dengan aplikasi makromediflash pada materi getaran.

Berikut ini adalah deskripsi masing-masing aspek sikap ilmiah siswa serta indikatornya pada pada pembelajaran Fisika Dengan media animasi makromediaflash :

\section{Aspek jujur}

Pada saat siswa melakukan percobaan mengenai getaran, siswa diminta untuk menuliskan hasil pengamatannya pada Lembar Kerja Siswa. Pengukuran terhadap sikap jujur siswa dilakukan menggunakan angket dan tercermin pada indikator 1. Rata-rata skor indikator tersebut (menyajikan data sesuai dengan pengamatan) tergolong kategori sangat baik (Gambar 1). Dari rata-rata indikator 1 diketahui aspek jujur merupakan aspek sikap ilmiah dengan rata-rata 3,7 yang merupakan rata-rata tertinggi dibandingkan dengan aspek sikap ilmiah yang lain. Berdasarkan rata-rata tersebut maka sikap jujur siswa termasuk dalam kategori sangat baik. Terlihat bahwa seluruh siswa telah memiliki sikap jujur dalam menyajikan hasil percobaaan mengenai getaran sesuai dengan hasil pengamatan yang dilakukannya. Data yang dilaporkan oleh siswa dalam LKS mereka adalah data yang benar-benar mereka peroleh saat melakukan pengamatan, bukan data yang dimanipulasi.

\section{Aspek ingin tahu}

Dalam melakukan percobaan mengenai priode dan prekuensi pada sebuah bandul sederhana, siswa diberikan kesempatan untuk mencari informasi sebanyak-banyaknya mengenai materi yang terkait dengan percobaan tersebut, dengan cara bertanya kepada guru maupun temantemannya. Pengukuran terhadap sikap ingin tahu siswa dilakukan menggunakan angket dan tercermin pada indikator 1 yakni menjawab pertanyaan guru dengan antusias, memperhatikan obyek yang di amati Perhitungan data menunjukkan rata-rata skor indikator 1 yakni 4,53 tergolong sangat baik.
Dari data terlihat siswa telah menunjukkan sikap ingin tahu terhadap materi yang terkait dengan percobaan, yang mereka tunjukkan dengan bertanya kepada guru dan teman jika mereka menemui masalah saat melakukan percobaan. Selain itu siswa juga banyak bertanya kepada guru mengenai penyebab terjadinya getaran.

\section{Aspek berpikir kritis}

Percobaan mengenai pengaruh pemberian simpangan terhadap priode dan frekuensi mendorong siswa untuk dapat berpikir kritis dalam menemukan konsep getaran. Pengukuran terhadap sikap berpikir kritis siswa dilakukan menggunakan angket dan tercermin pada indicator 4-5. Rata-rata skor indikator 4 (menanyakan perubahan baru dan mengulangi yang dilakukan) tergolong dalam kategori sangat baik, Dari perhitungan yang dilakukan diketahui bahwa rata-rata skor sikap berpikir kritis siswa adalah 4,4 dan tergolong dalam kategori sangat baik.

4. Aspek tekun

Pada saat siswa melakukan percobaan mengenai pengaruh simpangaan terhadap periode dan frekuensi siswa diharapkan dapat bersikap tekun karena diperlukan waktu pengamatan yang cukup lama. Pengukuran terhadap sikap tekun siswa dilakukan menggunakan angket dan tercermin pada indikator 6. Mengerjakan tugas yang di instruksikan dengan sungguh sungguh. Rata-rata skor indikator 4 (bersedia mengulangi eksperimen yang hasilnya meragukan) tergolong dalam kategori sangat baik, Ratarata skor aspek tekun siswa adalah 4,55 dan tergolong dalam kategori sangat baik.

\section{Terbuka}

Pada saat siswa melakukan percobaan mengenai pengaruh simpangaan terhadap periode dan frekuensi siswa diharapkan dapat bersikap terbuka karena diperlukan keseriusan pengamatan, jika belum faham boleh di tanyatakan pada guru ataupun kelompok, menghargai pendapat teman. Pengukuran terhadap sikap terbuka siswa dilakukan menggunakan angket dan tercermin Menghargai pendapat atau temuan orang lain. Rata-rata skor adalah 4,15 dan tergolong dalam kategori sangat baik.

\section{Tanggung Jawab}

Pada saat siswa melakukan percobaan mengenai pengaruh simpangaan terhadap periode dan frekuensi masing masing siswa dapat bertanggung jawab karena diperlukan keseriusan masing masing individu, semua siswa bertanggung jawab terhadap proses dan hasil pengamatan. Selain itu saat akhir pembelajaran dan diberikan tes siswa mengerjakan tugas demean penuh rasa tanggung jawab, Pengukuran terhadap tanggung jawab siswa dilakukan menggunakan angket dan tercermin pada 
indikator 9 yakni melakukan tes individu demean baik. Rata-rata skor aspek tekun siswa adalah 4,8 dan tergolong dalam kategori sangat baik.

\section{Jujur}

Percobaan mengenai pengaruh pemberian simpangan terhadap priode dan frekuensi mendorong siswa untuk bersikap jujur dalam menemukan hasil pengamatan, jujur ketika menjawab tes individu, tidak mencontek ke siswa lainnya Pengukuran terhadap sikap jujur siswa dilakukan menggunakan angket dan tercermin pada indicator 10 . (jujur ketika menjawab tes individu demean tidak mencontek) tergolong dalam kategori sangat baik, Dari perhitungan yang dilakukan diketahui bahwa rata-rata skor sikap berpikir kritis siswa adalah 4,7 dan tergolong dalam kategori sangat baik.

Sikap ilmiah pada hakikatnya adalah kecenderungan seseorang untuk berpikir dan bertindak secara ilmiah dalam mengerjakan sesuatu. Berdasarkan data sikap ilmiah diketahui bahwa rata-rata skor sikap ilmiah siswa kelas $\mathrm{X}$ SMKN 1 Lingsar Kabupaten Lombok barat, termasuk dalam kategori sangat baik. Data juga menunjukkan bahwa rata-rata skor aspek tertinggi adalah aspek tanggung jawab. Menurut Baharuddin (1982), sikap tanggung jawab harus dimiliki oleh seseorang yang ingin memecahkan masalah melalui langkah-langkah ilmiah. Seseorang harus dapat melihat sesuatu sebagaimana adanya obyek itu, menjauhkan bias pribadi dan tidak dikuasai oleh pikirannya sendiri. Dengan kata lain dapat bekerja dengan penuh tanggung jawab dan menjauhkan kepentingan dirinya sebagai subyek. Penggunaan model pembelajaran dengan media animasi ini menekankan pada penemuan konsep oleh siswa mendukung terbentuknya sikap berpikir kritis pada diri siswa. Pertanyaan analisis dalam Lembar Kerja Siswa. Membantu siswa untuk berpikir kritis dalam mencari penyebab terjadinya suatu fenomena [4].

\section{KESIMPULAN}

Berdasarkan hasil penelitian yang dilakukan ada beberapa hal yang dapat kami simpulkan antara lain sebagai berikut: Produk media media animasi pembelajaran fisika pokok bahasan getaran yang telah dikembangkan oleh peneliti dengan menggunakan perangkat lunak komputer macromediaflash termasuk dalam kategori sangat baik. Hasil validasi ahli media oleh validator 1 (Sukainil Ahzan M.Si) sebesar 3.4 dengan kategori sangat baik, sedangkan hasil validasi ahli materi oleh validator 2 (Dwi Pangga, M.Si) sebesar 3.3 dengan kategori sangat baik dan hasil perolehan skor rata-rata dari keseluruhan siswa/responden terhadap media animasi pembelajaran fisika yang dikembangkan termasuk dalam kategori sangat setuju. Dari 20 siswa/responden 5 siswa merespon dengan kategori setuju dan 15 siswa merespon dengan kategori sangat setuju. Dengan demikian media animasi pembelajaran fisika pokok bahasan getaran yang dikembangkan layak dijadikan sebagai media animasi pembelajaran

Pengembangan media animasi Dengan Aplikasi Makromedia Flash dapat menungkatkan sikap ilmiah siswa dengan kategori sangat baik pada 7 aspek yakni : terbuka, kritis, teliti, rasa ingin tahu, tekun, jujur, tanggung jawab.

\section{DAFTAR PUSTAKA}

[1] Doyan, Aris, dkk. 2014. Pengembangan Media Animasi Berbasis Macromedia Flash Pada Pelajaran Fisika Alat Optik. ISSN 2338-4417. PKPSM IKIP Mataram.

[2] Sugiyono. 2015. Metode Penelitan Pendidikan Pendekatan Kuantitatif, Kualitatif, dan $R \& D$. Bandung: Alfabeta.

[3] Eko Putro Widoyoko. (2012). Teknik Penyusunan Instrumen Penelitian. Yogyakarta: Pustaka Pelajar

[4] Purwaningsih (2007). Teori Belajar dan Pembelajaran. Yogyakarta: Gramedia Pustaka 